ton; Vice-Presidents who have filled the office of President, Prof. C. H. Lees, Sir Frank Smith, Sir Owen Richardson, Dr. W. H. Eccles, Prof. A. O. Rankine, T. Smith, Sir Charles Darwin, Prof. E. N. da C. Andrade, Sir David Brunt, Prof. G. I. Finch, Prof. S. Chapman and Prof. L. F. Bates; VicePresidents, Dr. D. Roaf, Dr. A. C. G. Menzies, J. H. Awbery and Dr. R. C. Evans; Honorary Secretaries, C. G. Wynne and Dr. H. H. Hopkins; Honorary Librarian, Dr. R. W. B. Pearse ; Honorary Foreign Secretary, Prof. E. N. da C. Andrade; Honorary Treasurer, A. J. Philpot; New Members of Council, Prof. R. W. Ditchburn, Dr. E. P. George, Dr. H. G. Kuhn and A. G. Peacock.

\section{Illuminating Engineering Society: Officers for 1952-53}

At the annual general meeting of the Illuminating Engineering Society held at Eastbourne on May 22, the following officers and new members of Council were elected : President, Dr. W. J. Wellwood Ferguson; Vice-Presidents, A. G. Higgins, E. C. Lennox, Alan H. Owen, J. F. Stanley and W. J. P. Watson; Honorary Treasurer, W. J. Jones; Honorary Secretary, H. C. Weston (32 Victoria Street, London, S.W.1) ; Honorary - Editor, Dr. W. E. Harper; New Members of Council, A. D. S. Atkinson, F. M. Hale, Dr. R. G. Hopkinson, R. A. Lovell, J. S. McCulloch, W. T. F. Souter, W. R. Stevens and D. L. Tabraham.

\section{University of Birmingham : Appointments}

THE title of reader in endocrinology has been conferred by the University of Birmingham on Dr. P. L. Krohn, lecturer in anatomy. The following have been appointed lecturers in the University : Dr. D. Mary Jackson (physiology), Dr. A. S. Jones (chemistry), J. Llewellyn (zoology), H. Rees (genetics), T. K. Ross and R. B. Shearn (chemical engineering), M. B. Stedman (geography) and I. Strachan (geology). The following have been appointed research fellows : A. Todrick and M. Piercy (neurological studies). The title of University research fellow has been conferred upon the following for the duration of their present appointments : L. Kerr, Royal Society Warren research scholar (electron physics), Dr. F. Shafizadeh (chemistry), Dr. J. G. Lawson and Dr. V. T. Brooks (mining), and Dr. D. Hamer and Miss D. M. Waldron (cancer research). Mr. L. Kuper has resigned from his post as lecturer in sociology in the University on appointment as professor of social science in the University of Natal.

\section{Announcements}

HoNORARY degrees of the University of Cambridge have been conferred on the following, among others : Mr. R. A. Butler, Chancellor of the Exchequer, and Hon. Fellow of Pembroke and of Corpus Christi Colleges ; Sir Edward Bailey, director during 193745 of the Geological Survey of Great Britain; Dr. K. T. Compton, president during $1930-48$ of the Massechusetts Institute of Technology ; Mr. O. G. S. Crawford, archæology officer of the Ordnance Survey during 1920-46; Sir Gordon Gordon-Taylor, the distinguished surgeon and past president of the Royal Society of Medicine.

DR. R. A. E. Galley, who has for the past year been seconded from the Agricultural Research Council to the Office of the Lord President of the Council, secretariat of the Advisory Council on
Scientific Policy, has been appointed, as from January 1, 1953, to be director of Colonial Products Research with the rank of deputy chief scientific officer, in succession to Sir John Simonsen, who is retiring. Dr. Galley will also take over responsibility for the work of the Colonial Products Advisory Bureau. Dr. J. R. Furlong, the present principal of the Bureau, who was due to retire at the end of this year, has agreed to remain in the Service for a further year as deputy director of Colonial Products Research.

A NEW Fatigue Testing Laboratory of the Eritish Welding Research Association (29 Park Crescent, London, W.1) will be officially opened at Abington Hall, Abington, near Cambridge, on June 23, by the Right Hon. Lord Woolton, Lord President of the Council.

THE first award of the English Electric research fellowship in aeronautics, which was recently established by the English Electric Company, Ltd., at the College of Aeronautics, Cranfield, has been made to Mr. G. C. C. Smith, a graduate in mechanical engineering of the University of Birmingham who is now in his final year of the postgraduate diploma course at the College of Aeronautics. The fellowship, which is worth $£ 500$ and is tenable for one year, is designed to promote studies in aeronautical engineering, with particular reference to the problems of vibration, stability and control of aircraft. Mr. Smith will undertake a structural research project during his tenure of the fellowship.

THE summer meeting and annual general meeting of the Society for Applied Bacteriology will be held in Cambridge during July 21-24. The programme will consist of sessions devoted to the reading of papers, local visits of interest, and a symposium on July 24 on "Aspects of Food Preservation". Further information can be obtained from the honorary secretary of the Society, G. Sykes, Boots Pure Drug Co., Ltd., Microbiology Division, Standards Department, Nottingham.

The Printing, Packaging and Allied Trades Research Association is holding a conference and exhibition at the Technical College, Shakespeare Street, Nottingham, during June 16-17, which will be repeated at the Assembly Room, Chamber of Commerce, New Street, Birmingham, during June 19-20. The conference will consist of three sessions, the first, a private one, being on "Research and the Printer", and the other two, open to the public, being on "Technical Progress" and a "Brains Trust", respectively. Further information can be obtained from the Association at Patra House, Randalls Road, Leatherhead, Surrey.

A summer school in programme design for automatic digital computing machines, on the same lines as those of previous years, will be held in the University Mathematical Laboratory, Cambridge, during September 16-26. The course will give a beasic training in the mathematical use of machines, dealing with the processes employed and their embodiment in programmes which specify the operation in detail. Lectures and practical classes will be held in the design of programmes for the Laboratory's electronic delay storage automatic calculator. Application forms, to be completed by July 14, can be obtained from G. F. Hickson, secretary of the Board of Extra-Mural Studies, Stuart House, Cambridge. 